\title{
Multilevel Analysis on the Bio-psychosocial and Environment Factors Affecting the Risk of Pneumonia in Infants
}

\author{
Astri Yunita'), Bhisma Murti²), Yulia Lanti Retno Dewi²) \\ 1) Masters Program in Public Health, Sebelas Maret University, Surakarta \\ 2)Faculty of Medicine, Sebelas Maret University, Surakarta
}

\begin{abstract}
Background: Pneumonia is an illness of the maincauses of pain and death in toddler in the world. The incidence of pneumonia in Indonesia has increased, from 2007 about $2.1 \%$ and in 2013 about2.7\%. Pneumonia in toddler in Indonesia is an issue that is important to do the actions of prevention and control of pneumonia. This study was aimed to investigate the factors biopsychosocial to the risk of pneumonia in toddlers.

Subjects and Method: This was an analytical observational study with case control design, carried out on 2 August to 16 September 2016. A total of 140 subjects in Banjarnegara, Central Java, were selected by fixed disease sampling. The dependent was pneumonia in infants. The independent variables were exposure to $\mathrm{CO}, \mathrm{H} 2 \mathrm{~S}$, family income, maternal education, household smoke exposure, sanitary home, chain-smoking family activity, anxiety. The data was collected by using a questionnaire, check list and recording and analyzed by using Logistic regression.

Results: There was influence of exposure of $\mathrm{CO}(\mathrm{OR}=1.46 ; 95 \% \mathrm{CI}=0.17$ to $21 ; \mathrm{p}=0.970)$, H2S $(\mathrm{OR}=0.53 ; 95 \% \mathrm{CI}=0.98$ to $2.92 ; \mathrm{p}=0.412)$, family income $(\mathrm{OR}=1.90 ; 95 \% \mathrm{CI}=0.78$ to $4.65 ; \mathrm{p}=$ $0.365)$, maternal education $(\mathrm{OR}=1.75 ; 95 \% \mathrm{CI}=0.72$ to $4.25 ; \mathrm{p}=0.474)$, household smoke exposure $(\mathrm{OR}=5.63 ; 95 \% \mathrm{CI}=2.27$ to $13.95 ; \mathrm{p}=0.001)$, home sanitation $(\mathrm{OR}=6.23 ; 95 \% \mathrm{CI}=2.61$ to $14.84 ; \mathrm{p}=0.001)$, smoking activity $(\mathrm{OR}=3.19 ; 95 \% \mathrm{CI}=1.33$ to $7.66 ; \mathrm{p}=0.020)$ and the incidence of pneumonia toddlers. There was the influence of anxiety to pneumonia in toddler $(\mathrm{OR}=16 ; 96 \%$ $\mathrm{CI}=6.87$ to $37.75 ; \mathrm{p}<0.001)$. There was the influence of contextual conditions to pneumonia in toddler (ICC $=36.97 \%$; role of thumb 5 to $8 \%$ likelihood ratio $\mathrm{p}=0.008$; $95 \% \mathrm{CI}=0.45$ to 8.17 ).

Conclusion: There is the influence of exposure to $\mathrm{CO}$, H2S, family income, maternal education, household smoke exposure, home sanitation, smoking activity. There is the influence of anxiety of pneumonia in toddler. The condition has influence contextual variations toddler pneumonia incident, so it is noteworthy.
\end{abstract}

Keywords: bio-psychosocial, environmental factor, pneumonia toddlers

\section{Correspondence:}

Astri Yunita. Masters Program in Public Health, SebelasMaret University, Surakarta. Email: astriyunita07@yahoo.co.id. Mobile: +6285641797995

\section{BACKGROUND}

$\overline{\text { Early childhood stage is a period of growth }}$ and development that should be concerned. In this stage the growth is slowing down, whereas development of gross motor and fine motor is increasing (Depkes, 2006). Early childhood age group is sensitive to nutrition needs and diseases. WHO (2010) explain that pneumonia is an infectious disease that becomes one of the leading causes of death worldwide. Pneumonia is a light lung infection (alveoli) that is caused by fungi, virus, bacteria, chemical exposure, and indirectinfluencefrom other diseases, therefore pneumonia is included as acute disease (Kemenkes RI, 2011).

Annually pneumonia accounts for 1.6 million deaths or $14 \%$, it becomes number 4 after measles 1\%, AIDS 2\% dan malaria 8\% (WHO, 2010). Pneumonia is categorized as a serious threat for industrialized and developing countries. Countries that focus on 
Journal of Epidemiology and Public Health (2016), 1(1): 1-10

https://doi.org/10.26911/jepublichealth.2016.01.01.01

pneumonia incidents every year are India (43 million), China (21 million), Pakistan (10 million), and 6 million in Bangladesh, Indonesia dan Nigeria (WHO, 2008).

Pneumonia incidents was increasing in 2007 (2.1\%) escalates to $(2.7 \%)$ in 2013 , it made the second place of the causes of death in Indonesia after diarrhea. Central Java has increasing number of pneumonia incidents in 2012 (24.74\%) to 2013 (25.85 $\%)$. Banjarnegara regency is a regency with the most number of toddlers who suffer from pneumonia and keep on increasing, in 2013 there were 7,555 patients, 2014 there were 7,532 patients and it was treated 45.5 $\%$; in 2015 there were 10,059 patients and $46.6 \%$ was treated.

Batur sub-district is one of sub-districts in Banjarnegara regency that lays in the highest region compared to other ssbdistricts that is in 2,065 masl. It has two Puskesmas (Community Health Center), those are Puskesmas Batur 1 and Puskesmas Batur 2 that possess high rate of pneumonia incidents in Banjarnegara Regency. Incident rate of pneumonia in 2014 was 349 toddlers and it was increasing in 2015 to 687 toddlers with pneumonia.

Environmental condition of Batur Subdistrict consists of some regions that are exposed with various level of $\mathrm{CO}_{2}, \mathrm{SO}_{2}, \mathrm{H}_{2} \mathrm{~S}$, and $\mathrm{CO}$, some regions are high, others are low. Measuring effort to determine gas spots with high and low concentration had been conducted by Geological Agency-Center for Volcanology and Geological Hazard Mitigation, which aimed to give information toward the condition of surrounding society (Supriyati, 2007).

Poor environmental condition and house arrangement such as insufficient lighting (including ultraviolet light), insufficient ventilation, humid rooms, overly dense rooms, and exposure of household smoke inside the house such as the usage of fire wood for cooking in kitchen is one of the causes of pneumonia incidents on toddlers (Ezzati dan Kammen, 2001).

Health behavioral factor is at risk to contagious diseases, such as clean and healthy behavior in Banjarnegara Regency is still low especially in Puskesmas Batur 1 the number of participants who carry out CHB is only $48.5 \%$. John Bordon elaborates epidemiology triangle (host, agent dan environment), which are connected to pneumonia such as low birth weight history, insufficient breastfeeding, immunization status, home sanitation, air pollution both inside and outside the house also Vitamin A deficiency (Hananto, 2004 dan Rudan, 2008).

Prevention effort in eliminating pneumonia on toddlers has been carried out by Indonesian government through immunization (Difteri Pertusis Tetanus and campak) and non immunization (Exclusive breastfeeding, good nutrition intake, environment improvement, clean and healthy behavior as well as avoiding the exposure of smoke from cigarette and kitchen (Misnadiarly, 2008).

Based on the description above it may be concluded that pneumonia on toddlers in Indonesia is an important issue to be resolved by controlling it from various factors also considering micro and macro levels, which determine the condition of patients' surrounding environment. HLBloom elaborates that health is affected by healthcare service, individual, life style and environment.

The purpose of the study was analyzing the effect of $\mathrm{CO}_{2}, \mathrm{SO}_{2}, \mathrm{CO}$ and $\mathrm{H}_{2} \mathrm{~S}$ exposure, household smoke exposure, home sanitation, family income, maternal education and family smoking activity toward the risk to pneumonia incidents on toddlers with multilevel analysis approach 


\section{SUBJECTS AND METHOD}

The study was an observational analytic with case control design. The study was conducted in Batur Sub-district, Banjarnegara Regency on 1 August 2016 to 14 September 2016. The independent variables were $\mathrm{Co}, \mathrm{H}_{2} \mathrm{~S}$, family income, maternal education, household smoke exposure, home sanitation, smoking activity, and toddlers' anxiety. The dependent variable was toddlers' pneumonia. The targeted research population was toddlers in Banjarnegara Regency region. Source population (accessible population) of the study was toddlers in Batur sub-district Banjarnegara Regency.

A total sample of 140 toddlers aged 2 month to $<5$ years old were selected by

Table 1. Characteristics of research subjects

\begin{tabular}{llcc}
\hline Characteristics & \multicolumn{1}{c}{ Criteria } & Frequency & Percentage (\%) \\
\hline Toddlers' age & 2 months - < 5 years & 140 & 100 \\
Mothers' age & < 20 years & 13 & 9.28 \\
& 20 - 35 years & 125 & 89.28 \\
Education & > 35 years & 2 & 1.44 \\
& Primary Level & 85 & 60.72 \\
Occupation & Secondary Level & 55 & 39.28 \\
& Farm laborer & 33 & 23.58 \\
& Farmer & 3 & 2.14 \\
& Self employed/ merchant & 2 & 1.42 \\
& Factory/ Industrial Laborer & 27 & 19.29 \\
& Unemployed & 75 & 53.57 \\
\hline
\end{tabular}

fixed disease sampling with comparison of without disease (control). Data collection techniques used were questionnaires, checklist, and medical record. The data were analyzed by using Logistic Regression Analysis with Multilevel approach using Stata 13 program.

\section{RESULTS}

\section{Characteristics of Study Subjects}

The result of research subjects characteristics in table 1 shows that 140 research subjects possess various distributions. Research variable descriptions are elaborated based on characteristics, criteria, frequency, and percentage 1:1 between group with disease (case) and
The comparison between pneumonia and non pneumonia study subjects was balance that is 50\%:50\%. Most study subjects are not exposed to $\mathrm{CO}_{2}$ (oppm) there were 140 study subjects (100\%), there were 140 study subjects (100\%) who were not exposed to $\mathrm{SO}_{2}$ (oppm), there were 125 study subjects (89.3\%) exposed to low CO (o.1-50 ppm), there were 116 study subjects (82.9\%), exposed to low $\mathrm{H}_{2} \mathrm{~S}$ (0.1-20 ppm).

There were 77 study subjects (55\%) exposed to household smoke, there were 73 study subjects (52.1\%) owned good home sanitation, there were 80 study subjects (57.1\%) whose family income was less that
Regional Minimum Wage (Rp. 1.265.000) there were 75 study subjects (53.6\%) unemployed, there were 85 study subjects (60.7\%) had primary level education background (low), there were 89 research subjects (63.6\%) who had smoking family members and most of the toddlers, that were 79 study subjects (56.4\%) were anxious when they got pneumonia.

\section{Bivariate Analysis}

Research variables were toddler pneumonia $\mathrm{CO}_{2}$ exposure, $\mathrm{SO}_{2}$ exposure, $\mathrm{H}_{2} \mathrm{~S}$ exposure, $\mathrm{CO}$ exposure, household smoke exposure, home sanitation, family income, maternal education, family smoking activity and 
Journal of Epidemiology and Public Health (2016), 1(1): 1-10

https://doi.org/10.26911/jepublichealth.2016.01.01.01

toddlers' anxiety level were analyzed by Chi Square.

Table 2. Bivariate analysis result

\begin{tabular}{lcccc}
\hline \multirow{2}{*}{ Independent Variables } & \multirow{2}{*}{ OR } & $\mathbf{p}$ & \multicolumn{2}{c}{ CI 95\% } \\
\cline { 5 - 5 } & & & Upper Limit & Lower Limit \\
\hline CO Exposure & 1.16 & 0.785 & 0.39 & 3.39 \\
$\mathrm{H}_{2}$ S Exposure & 1.00 & 1.00 & 0.41 & 2.40 \\
Household Smoke Exposure & 3.98 & $<0.001$ & 1.96 & 8.07 \\
Home Sanitation & 4.47 & $<0.001$ & 2.19 & 9.10 \\
Family Income & 3.33 & 0.001 & 1.65 & 6.72 \\
Maternal Education & 1.94 & 0.057 & 0.97 & 3.87 \\
Smoking Activity & 2.57 & 0.008 & 1.26 & 5.25 \\
\hline
\end{tabular}

3. Logistic Regression Multivariate Analysis with Multilevel Approach

Table 3. The result of logistic regression analysis with multilevel approach of biopsychosocial and environmental factors toward the risk of pneumonia incidents on toddlers

\begin{tabular}{|c|c|c|c|c|}
\hline \multirow{2}{*}{ Independent Variables } & \multirow{2}{*}{$\mathbf{O R}$} & \multicolumn{2}{|c|}{ CI(95\%) } & \multirow{2}{*}{$\mathbf{p}$} \\
\hline & & Lower Limit & Upper Limit & \\
\hline \multicolumn{5}{|l|}{ Fixed Effect } \\
\hline CO Exposure & 1.46 & 0.17 & 12.13 & 0.970 \\
\hline $\mathrm{H}_{2} \mathrm{~S}$ Exposure & 0.53 & 0.98 & 2.92 & 0.412 \\
\hline Household smoke exposure inside the house & 5.63 & 2.27 & 13.95 & $<0.001$ \\
\hline Home sanitation & 6.23 & 2.61 & 14.84 & $<0.001$ \\
\hline Family Income & 1.90 & 0.78 & 4.65 & 0.365 \\
\hline Maternal Education & 1.75 & 0.72 & 4.25 & 0.474 \\
\hline Family smoking activity & 3.19 & 1.33 & 7.66 & 0.020 \\
\hline \multicolumn{5}{|l|}{ Random Effect } \\
\hline \multicolumn{5}{|l|}{ Neighborhood area } \\
\hline $\operatorname{Var}($ constanta $)$ & 1.92 & 0.45 & 8.17 & \\
\hline Conformity of ICC (Intraclass Correlation) & & & & \\
\hline Model & $36.97 \%$ & & & \\
\hline
\end{tabular}

The influence in multivariate manner elaborates the effect of bio- psychological and environmental factors to pneumonia incidents on toddlers

Table 3 shows that ICC $=36.97 \%$, the indicator shows that the area condition of each neighborhood has contextual influence toward the variation of toddlers pneumonia occurrence as much as $36.97 \%$. The figure is bigger than the standard figure of role of thumb which is by $5-8 \%$, therefore the contextual influence of neighborhood area condition presented by multilevel analysis is important to concern about. The table shows the likelihood ratio $=0.008$ that means there is statistically significant difference between model that does not consider contextual influence and model that consider contextual influence, in this term is the area condition of each neighborhood.

\section{DISCUSSION \\ 1. The Influence of $\mathrm{CO}$ and $\mathrm{H} 2 \mathrm{~S}$ Expo- sure toward Pneumonia Incidents on Toddlers}

The study result showed that toddlers who lived in environment that is exposed to $\mathrm{CO}$ 
and $\mathrm{H}_{2} \mathrm{~S}$ were likely to have bigger risk to catch pneumonia compared to toddlers who lived in environment that was not exposed to $\mathrm{CO}$ and $\mathrm{H}_{2} \mathrm{~S}$. The $\mathrm{CO}_{2}$ and $\mathrm{SO}_{2}$ exposure resulted in there was no exposure at all in the toddlers residential. It indicated that there was no $\mathrm{H}_{2} \mathrm{~S}$ effect, however there was effect of $\mathrm{CO}$ exposure to toddler pneumonia incident and it was not significant.

It is in accordance with Soemirat (2015) statement, which elaborate that poor home condition may disturb body health, as the result of insufficient oxygen within the air, whereas carbon dioxide is increasing.

Factors that may increase the risk of pneumonia were such as toddlers' characteristics, home condition, the source of air pollution inside and outside as well as residential density. Toxic gas such as carbonmonooxide (CO) may cause asphyxia effect in which bind hemoglobin $(\mathrm{COHb})$ that generates the disruption of oxygen stream inside body, since there is too much carbon dioxide.

The exposure of $\mathrm{CO}_{2}, \mathrm{SO}_{2}, \mathrm{CO}$ dan $\mathrm{H}_{2} \mathrm{~S}$ around the house was below normal limit with safe distance was at about 1000 meter from crater, even $\mathrm{CO}_{2}$ and $\mathrm{SO}_{2}$ did not spread around people housing, only around the crater as the process of natural phenomenon. Whereas $\mathrm{CO}$ and $\mathrm{H}_{2} \mathrm{~S}$ were also categorized as below normal so that it did not rapidly affect health. $\mathrm{CO}_{2}, \mathrm{SO}_{2}, \mathrm{CO}$ and $\mathrm{H}_{2} \mathrm{~S}$ do not spread too highly since $\mathrm{CO}_{2}, \mathrm{SO}_{2}, \mathrm{CO}$ and $\mathrm{H}_{2} \mathrm{~S}$ will be decompounded by sunlight therefore they do not give any effect to health (Surip, 2016). Timbang Crater is one of the Craters in Dieng that has high concentration of $\mathrm{CO}_{2}$ exposure as much as $1.8 \%$ volume or $18,000 \mathrm{ppm}, \mathrm{H}_{2} \mathrm{~S}$ concentration is as much as $0.6 \mathrm{ppm}$ dan $\mathrm{SO}_{2}$ is as much as $0.2 \mathrm{ppm}$.

Based on that matters it can be concluded that there was an effect of $\mathrm{CO}_{2}$ and $\mathrm{H}_{2} \mathrm{~S}$ exposure to pneumonia incidents on toddlers. Therefore the result of the study is in accordance with the previous study and the existing theory.

\section{The Influence of Household Smoke Exposure inside the House toward Pneumonia Incident on Toddlers}

Study result showed that toddlers who lived in a house that was exposed by household smoke were likely to have five times bigger risk to pneumonia compared to toddlers who lived in a house that was not exposed to household smoke inside the house. The smoke might come from the use of fire wood for cooking.

The study result is in accordance with the study made in Birmingham (England) which states that the increasing risk to pneumonia may come from the exposure of fuel burning smoke, and there are some evidences that the use of stove may reduce smoke exposure. The study made by Maskey et al., (2012) in Nepal states that around $87 \%$ of households used solid biomass as the main source of fuel, and as many as 1,284 caught acute respiratory tract infection and pneumonia.

The study by Pribadi (2008) conveys houses that use firewood to cook have OR value 6.8 times in increasing the risk of pneumonia incidents on toddlers. According to Depkes (2012), indoor air pollution such as the use of mosquito coil, cooking fuel, and the existence of smoker may increase the risk to pneumonia incidents on toddlers.

Batur sub-district is a region with low temperature and the average Dieng family usually using stove and firewood for cooking, besides they also have habit of using charcoal hearth to warm house temperature, that is usually done at night during family time. It obviously increases air exposure toward body condition especially for toddlers who are more vulnerable. Charcoal as well as firewood contains carbon mono- 
Journal of Epidemiology and Public Health (2016), 1(1): 1-10

https://doi.org/10.26911/jepublichealth.2016.01.01.01

xide, organic gas, particulate matter, and nitrite oxide, that may increase health disruption toward body, such as respiration problem.

There were seven questions to know the effect of smoke exposure inside house toward pneumonia incidents on toddlers, that get the higher score was number 6 about kitchen lighting, it fitted with most home sanitation condition that were categorized as unhealthy. Insufficient lighting in kitchen area generates the growth of germs. There were quite a lot who answered "yes" for the first question that was the absence of ventilation in the kitchen. It obviously increased the risk of respiration problems, sinceinsufficient ventilation leads to disrupted air flow.

Based on that matter it can be concluded that therewas the influence of household smoke to pneumonia incidents on toddlers. Thus, the result is in accordance to the previous study and the existing theory.

\section{The Influence of Home Sanitation toward Pneumonia Incident on Toddlers}

The result of the study shows that toddlers living in a house with poor home sanitation were likely to have risk six times bigger to catch pneumonia compared to toddlers living in a house with good sanitation. The study result was in accordance with a study by Pribadi (2008), that elaborates physical environment of a house which does not meet health requirements may support the occurrence of disease transmission and ailment such as pneumonia. Physical environment risk factors in the study have OR value 7.4 times in increasing the risk of pneumonia incidents on toddlers. Government has stipulated a regulation on housing health requirements that is Stipulation of Health Minister No. 829/MENKES/SK/VII /1999 about Housing Health Requirement
Based on the study by Azhar and Perwitasari (2013), condition of physical environment that does not meet the health requirement and the behavior of using fuel may increase the risk of diseases such as $\mathrm{TB}$, cataract and pneumonia. In Indonesia housing proportion that meets the requirement of healthy house is still low, that is 24.9\%.

Based on AHPHA (American Public Health Association) it suggests to use ventilation as the effort to reduce the emergence of indoor air pollution as well as outdoor. There were 13 statements to know the condition of people's home sanitation, the highest result is on statement no. 5 and 12 that show the occurrence of object which blocks air flow at the window and bedroom which is occupied by two or more people. The occurrence of objects that block air flow leads to the decreasing of oxygen level, increasing of carbon dioxide, musty smell, increasing room temperature, and generates the increasing humidity. the use of bedroom by more than two people increases the risk to catch pneumonia by 1.8 times bigger.

Based on the above elaboration it can be concluded that there was an influence of home sanitation to pneumonia incidents on toddlers. Therefore the result is in accordance with the previous study and the existing theory.

\section{The Influence of Family Income toward Pneumonia Incidents on Toddlers}

The result of the study shows that there was an influence and it was insignificant between family income and pneumonia incidents on toddlers. Toddlers who were living with family with low income were likely to have two times bigger risk compared to toddlers who were living with high income. The result of the study is in accordance with the study conducted by Becker et al., 
(2006) which concludes that social economy status is not related to pneumonia incidents. The study conducted by Kosai et al (2015) also states that there is a significant relationship between social economy status with the increasing risk of pneumonia on toddlers.

In this study most of the respondents wereunemployed, meaning to say they were housewives, and some others were farm laborers and industrial laborers, therefore occupation and income were a whole unity to support buying power of a family. The requirements for a healthy house are not necessarily met by expensive price, for example to build a safe and comfortable house, cold brick wall can be substituted by wood and supported by the activity to clean the house and open the windows regularly.

Based on the above elaboration it can be concluded that there was an influence of family income to pneumonia incidents on toddlers. Therefore the result is in accordance with the previous study and the existing theory.

\section{The Influence of Maternal Educa- tion toward Pneumonia Incidents on Toddlers}

The result of the study shows that there was an influence and it was insignificant between maternal level of education with pneumonia incidents on toddlers. Toddlers whose mothers had primary or lower education background had 1.75 times bigger risk to suffer from pneumonia compared to toddlers whose mother had secondary or higher education background. The result of the study by Herman (2002) elaborates that education does not have any significant relationship with pneumonia incidents with the value of OR is 1.1.

Based on education background in Batur Sub district with the total number of research subjects was 140, 65 of them had high education, the rest had low education background. It did not create extensive gap in term of education. One's knowledge is the result of education which is not obtained only from formal education, however non formal education may also improve society's knowledge. One's background may influence the attitude and behavior based on the knowledge they have.

Health education for the prevention of pneumonia on toddlers is one of the efforts to prevent pneumonia on toddlers. The nature of health education is an activity or effort to deliver health messages to society, groups and individuals to obtain better knowledge abouthealth. Information obtained either from formal or non formal education may give immediate impact so that it results in knowledge change or improvement.

Based on the above elaboration it can be concluded that there was the influence of maternal education toward pneumonia incidents on toddlers. Therefore the result is in accordance with the previous study and the existing theory.

\section{The Influence of Family Smoking Activity toward Pneumonia Inci- dents on Toddlers}

The study result show that toddlerswho live with smoking family members are likely to have three times bigger risk to catch pneumonia compared to toddlers who live with non smoking family member. Macro environment that may influence toddlers' health may get affected by disease or maternal behavior such as smoking as active smoker, so that toddlers may get exposed by smoke (smokers)

The result of the study is in accordance with the study in France and the study by Duta (2009) in India which gives strong evidence that one of the causes of indoor air pollution is cigarette smoke that contains ultrafine particle which cause acute respiratory tract infection on toddlers. Another 
Journal of Epidemiology and Public Health (2016), 1(1): 1-10

https://doi.org/10.26911/jepublichealth.2016.01.01.01

study that show the significant relationship between smoking and pneumonia on toddlers is a study by Gertudris (2012) with value of $\mathrm{p}=0.03$ and $\mathrm{OR}$ value is 1.8 .

Toxic and carcinogenic materials within cigarette smoke have the similar effect on both active and passive smokers. It generates irritation effect on respiratory tract for the content of sulfurdioxide, ammoniac, and formaldehyde (Hidayat et al., 2012).

Based on the elaboration above then it can be concluded that there was the influence of family smoking activity to pneumonia incidents on toddlers. Therefore the result is in accordance with previous study and the existing theory.

\section{The Influence of Pneumonia on Toddlers to Toddlers' Level of An- xiety}

The result of the study shows that toddlers who suffer from pneumonia had high level of anxiety compared to toddlers who did not suffer from pneumonia. Toddlers with pneumonia were likely to have 16 times bigger risk to endure anxiety than toddlers without pneumonia. Agustinus (2015), states that whenever sort of breath, heart beats fast, dry mouth, and sweaty palm occur then it will lead to anxiety reaction.

Based on the above elaboration it can be concluded that there was the influence of pneumonia to toddlers' level of anxiety. Therefore it is in accordance with the previous study and theory.

\section{The Influence of Neighborhood Con- ditiontoward Pneumonia Incidents on Toddlers}

The result of multilevel analysis showed that $\mathrm{ICC}=36.97 \%$, the indicator showed that the area condition of each neighborhood had contextual influence toward the variation of pneumonia incidents on toddlers.

Gordon theory in the book Candra, (2007) shows the interaction between bac- teria (agent), human (host) and environment, the environment outside the individual (host) play important role in the increasing of pneumonia on toddlers. Based on the findings in the field neighborhood area affected the incidents of pneumonia on toddlers, since the housing condition of each neighborhood was different, the distance between houses in some neighborhood was quite far, so that the air flow to each house was better than those with narrow space between houses and populated, in which the lighting was often blocked by other houses.

In addition, prevention toward diseases conducted by each neighborhood was different; in the neighborhood with high awareness toward health the people would affect the surrounding to be aware of health also. People who lived in the neighborhood with less awareness toward health were likely to get affected and unaware of their negative behavior.

It can be concluded that there were influences of $\mathrm{CO}_{2}, \mathrm{H}_{2} \mathrm{~S}$ exposure, family income, maternal education, household smoke exposure, home sanitation, family smoking activity. There was influence of toddlers' pneumonia toward toddlers' anxiety. Condition of each neighborhood had contextual influence toward the variation of pneumonia incidents on toddlers, therefore it needs to be noticed.

\section{REFERENCE}

Agustinus (2015). Phobia. Surabaya: Rama Press Institut.

Anwar A, Dharmayanti I (2014). Pneumonia pada Anak Balita di Indonesia. Jurnal Kesehatan Masyarakat Nasional 8(8).

Azhar K, Perwitasari D (2013). Kondisi Fisik Rumah dan Perilaku dengan Prevalensi Paru di Provinsi DKI Ja- 
karta, Banten dan Sulawesi Utara. Media Litbangkes 23(4).

Becker S, Fonseca BF, Yglesias CS (2006). Husbands and Wives Reports of Women's Decision Making Power in Western Guatemala and Their Effect on Preventive Health Behaviors. Social Science and Medicine 62 (9).

Departemen Kesehatan Republik Indonesia (2012). Manajemen Terpadu Balita Sakit (MTBS). Jakarta: Modul 1-7.

Duta, Biswas. (2009). Risk Factors of Acute Respiratory Infections in Underfives of Urban Slum Community.

Ezzati M, Kammen DM (2001). Quantifying The Effects of Exposure to Indoor Air Pollution From Biomass Combustion on Acute Respiratory Infections in Developing Countries. Journal of Environmental Health Perspectives 109 (5).

Gertudris T (2012). Hubungan Antara Kadar Partikulat (PM10) Udara Rumah Tinggal dengan Kejadian ISPA pada Balita di Sekitar Pabrik Semen PT Indocement, Citereup (Tesis). Depok: Fakultas Kesehatan Masyarakat Universitas Indonesia.

Hananto M (2004). Analisis Risiko yang Berhubungan dengan Kejadian Pneumonia pada Balita di Empat Provinsi di Indonesia (Tesis). Depok: Fakultas Kesehatan Masyarakat Universitas Indonesia.

Herman (2002). Faktor-faktor yang Berhubungan dengan Kejadian Pneumonia pada Anak Balita. Jakarta: Fakultas Kesehatan Masyarakat Universitas Indonesia.

Hidayat S, Yunus F, Susanto AD (2012). Pengaruh Polusi Udara dalam Ruangan terhadap Paru. Departemen Pulmonologi dan Ilmu Kedokteran Respirasi Fakultas Kedokteran Universitas Indonesia, 39(1).
Kementerian Kesehatan Republik Indonesia (2011). Pedoman Pengendalian Infeksi Saluran Pernapasan Akut. Jakarta: Badan Direktorat Jenderal Pengendalian Penyakit dan Pengendalian Lingkungan, Kementerian Kesehatan Republik Indonesia.

Kosai H, Tamaki R, Saito M, Tohma K, Alday PP, Tan AG, Inobaya MT (2015). Incidence and Risk Factors of Childhood Pneumonia-Like Episodes in Biliran Island, Philippines-A Community-Based Study. Journal Plos One 10(5).

Maskey AP, Day JN, Tuan PQ, Thwaites GE, Campbell JI, Zimmermen M, Farrar JJ (2006). Salmonella Enterica Serovar Paratyphi A and S. Enterica Serovar Thypi Cause Indistinguishable Clinical Syndromes in Kathmandu, Nepal. Oxford UK. Journal of Infectious Disease 42 (9).

Misnadiarly (2008). Penyakit Infeksi Saluran Napas Pneumonia Pada Anak, Orang Dewasa dan Usia Lanjut. Jakarta: Pustaka Obor.

Pribadi S (2008). Faktor-faktor Lingkungan Fisik Rumah dan Perilaku yang Berhubungan dengan Kejadian Pneumonia Pada Balita di Kabupaten Pontianak. Jurnal Kesehatan Lingkungan:Universitas Diponegoro.

Prietsch SOM, Fischer GB, Cesar JA, Lempek BS, Barbosa JrLV, Zogbi L, Cardoso OC (2008). Acute Lower Respiratory Illness in Under-five Children in Rio Grande Brazil: Prevalence and Risk Factors. Journal of Brazil, 24(6).

Rudan I, Pinto CB, Biloglav Z, Mulholland K, Campbell H (2008). Epidemiology and Etiology of Childhood Pneumonia. Bulletin World Health Organization, 86(5). 
Journal of Epidemiology and Public Health (2016), 1(1): 1-10

https://doi.org/10.26911/jepublichealth.2016.01.01.01

Soemirat SJ (2015). Mortality and Morbidity as Related to Air Polution. A Paper. University of Minnoseto.

Supriyati DA (2007). Sebaran dan Bahaya $\mathrm{CO} 2$ di Kompleks Vulkanik Dieng. Departemen Energi dan Sumber Daya Mineral, Badan Geologi, Pusat Vulka- nologi dan Mitigasi Bencana Geologi, Balai Penyelidikan dan Pengembangan Teknologi Kegunungapian.

WHO (2008). Manajemen Terpadu Balita Sakit. Jakarta: Depkes RI.

WHO (2010). The Global Burden Disease. Jakarta: Depkes Republik Indonesia. 